\title{
Effect of Paper Mill Effluent on Lipid Profile of Freshwater Snake Headed Fish, Channa punctatus (Bloch, 1793)
}

\author{
Sadguru Prakash ${ }^{1}$, , Sushil Kumar Upadhyay 2,*(D) \\ 1 Department of Zoology, M.L.K. (P.G.) College, Balrampur (U.P.), India; \\ 2 Department of Biotechnology, Maharishi Markandeshwar (Deemed to be University), Mullana-Ambala (Haryana)- \\ 133207, India; \\ * Correspondence: upadhyay.k.sushil@gmail.com (S.K.U.);
}

Scopus Author ID 57197228358

Received: 29.07.2021; Revised: 26.08.2021; Accepted: 28.08.2021; Published: 4.09.2021

\begin{abstract}
Industrial effluents reaching the aquatic ecosystem through various routes like run-off, leaching, and direct discharge from factories are major causes of environmental pollution. These were reported to have a negative metabolic impact on different non-target aquatic organisms. Fish is a close inhabitant of the aquatic environment, serves as a useful model for assessing the effect of chemicals mixed in the aquatic environment. Channa punctatus Bloch (Actinopterygii: Channidae), one of the most common edible fish, if exposed to industrial effluents containing harmful substances, maybe a serious threat to human health. In the present study, an attempt was made to understand the effect of sublethal concentrations of paper mill effluent on lipid profiles of Channa punctatus after exposure to 96 hours. A significant increase was observed in total serum lipid, cholesterol, and phospholipid with decreased triglyceride levels. A significant increase was observed in the cholesterol and triglycerides levels, whereas total lipids and phospholipid levels showed a marked decline in the liver. Thus present study concludes that the estimation of the lipids profile of fish will certainly detect early signs of stress physiology concerning their habitat.
\end{abstract}

Keywords: Channa punctatus; cholesterol; phospholipids; triglycerides; paper mill effluent. Abbreviations: $\mathrm{KMnO}_{4}$-Potassium Permanganate; $\mathrm{V}_{\mathrm{E}}-$ Volume of Effluent; $\mathrm{V}_{\mathrm{DW}}$-Volume of Dilution Water; FAO-Food and Agriculture Organization; S.E.-Standard Error (S.E.); LC 50,-Lethal Concentration with 50\% mortality; M..-Molarity; mg/l-Milligram per Liter; L-Liter; Hrs.-Hours.

(C) 2021 by the authors. This article is an open-access article distributed under the terms and conditions of the Creative Commons Attribution (CC BY) license (https://creativecommons.org/licenses/by/4.0/).

\section{Introduction}

Rapid urbanization and industrialization in India resulted in a substantial increase in the liquid waste traditionally discharged in open land or into nearby natural water bodies, causing many environmental problems, including a threat to aquatic biota [1-4]. Industrial discharges and wastes are the undesired outcomes of economic development and technological advancement [5-7]. In India, only $60 \%$ of 13,500 million liters or more of industrial effluent discharged daily by industries is treated, and rests remain untreated [8-10]. The industrial wastewater carrying various noxious and toxic contaminants and heavy metals discharged into rivers, streams, and other aquatic reservoirs regularly and disturbed the cell's normal functioning [11-14]. This may lead to alternation in aquatic animals' functional biochemical and physiological mechanisms and is likely to affect the growth and production of aquaculture 
adversely [15-17]. Many of the toxic substances released from these industries are lipophilic and accumulate in fatty tissues of aquatic animals like fishes or become protein-bound, so it is of importance to know the critical concentration above which human beings are affected, and the commercial fish species become unsuitable food [18-21].

After agriculture evolution, the intensive application of pesticides without proper disposal management has led their excess residues to reach the neighboring aquatic ecosystem through various routes like run-off, leaching, spray-drift, industrial effluent, and its inhabitants, mainly fish [22-24]. The effluent drainage from different industrial units poses a serious threat to the aquatic flora and fauna [25-27]. Industrial effluents carry many toxic substances capable of affecting the genetic material of the organisms, leading to immediate and inherited mutation [28-30]. A variety of somatic diseases like cell death, immunological impairment, ineffective tissue repair, premature aging, and carcinogenesis may also result from the chemicals in the effluents [31-33]. As per some earlier reports, the industrial effluents exposure among fishes exhibited different behaviors such as schooling where fishes form groups; surfacing, i.e., frequent movement to water surface; hanging due to loss of balance, opercular movement rate, and convulsions [34-36]. Due to effluents exposure, these behaviors among fishes were subjected to effluents exposure were subjectedto sensory organs, neuromuscular coordination, and affect the fish metabolism in diversified manners [37, 38].

India has $20^{\text {th }}$ rank among the paper-producing countries in the world. The most important problem the paper industries are facing today is the disposal of tremendous volumes of wastewater [39-43]. Paper and pulp mills use a huge quantity of freshwater during scouring, bleaching, digesting, rinsing, cortication, lime treatment, and other finishing processes and return a large quantity of wastewater containing undesirable impurities [44-48]. The Indian paper industry consumes about $250 \mathrm{~m}^{3}$ of freshwater per ton of paper and generates the corresponding wastewater [49-51]. In India, around 905.8 million $\mathrm{m}^{3}$ of water is consumed, and around 695.7 million $\mathrm{m}^{3}$ of wastewater is discharged annually by this sector $[52,53]$. So paper mills are normally located at the banks of rivers to ensure an adequate supply of water and a means of disposing of effluents, which are generally characterized by high concentrations of chemical oxygen demand, biological oxygen demand, suspended solids, extreme $\mathrm{pH}$, and elevated temperatures [54-57]. The discharged effluents made the water unfit for human consumption and create health hazards in various aspects if consumed directly or indirectly [58-62]. The use of the biochemical approach has been advocated to provide an early warning to potentially damaging changes in stressed organisms [63-66]. Accordingly, the health of aquatic organisms is influenced by the physiological activities taking place in their body [6769]. Lipids play an important role in the architectural dynamics of the cell and transport mechanism across the cell membrane [70-73]. Lipids also contribute to energy production as they have high caloric values and play a vital role in the biochemical adaptations of animals to stress conditions [74-78]. Hence, the present investigation is aimed to study the effect of sublethal concentrations of paper mill effluent on the lipid metabolism of Channa punctatus.

\section{Materials and Methods}

\subsection{Procurement of test fish.}

Healthy specimens of snake-headed fish, Channa punctatus Bloch (Actinoptrygii: Channidae) with bodyweight $45 \pm 5 \mathrm{~g}$ and body size $12 \pm 5 \mathrm{~cm}$, were collected from a local fish farm Balrampur (Uttar Pradesh), India, and were transported to the laboratory. The fishes were 
carefully examined for any injury and then kept in $1 \%$ solution of $\mathrm{KMnO}_{4}$ for few hours to get rid of dermal infection. These were further kept in a large plastic jar containing 50L of clean tap water and acclimatized for 15 days to the laboratory conditions. During these periods, the fishes were fed on boiled egg yolk and commercial fish food.

\subsection{Collection of paper mill effluent.}

The treated effluent samples were collected from Yes Paper Mill Ltd. Darshan Nagar, Ayodhya (Uttar Pradesh), India, in a polyethylene container. The percent concentration of test solution has been calculated using the formula after FAO [79]:

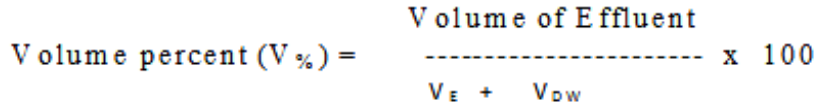

Where, $\mathrm{V}_{\mathrm{E}}=$ Volume of effluent; $\mathrm{V}_{\mathrm{DW}}=$ Volume of Dilution water.

\subsection{Plan of the experiment.}

The $\mathrm{LC}_{50}$ for treated paper mill effluent for 96 hours was $15 \%$ after Prakash and Verma [80]. Based on reference $\mathrm{LC}_{\mathbf{5 0}}$, fishes were exposed to sublethal concentrations (10\%) of paper mill effluent for the period of 24, 48, 72, and 96 hours. A control group was also maintained in an identical environment for the same periods viz. 24, 48, 72, and 96 hours. The fishes of both groups were regularly fed with commercial food, and the medium was changed daily to remove feces and food remnants. The fishes were sacrificed immediately at the end of 24, 48, 72, and 96 hours in both experimental and control groups.

\subsection{Blood sample collection.}

The blood samples were collected from live fishes through a cardiac puncture in both experimental and control groups at 24, 48, 72, and 96 hours exposures. These were allowed to stand for some time and, after that, centrifuged at $3500 \mathrm{rpm}$ for $10 \mathrm{~min}$ to obtain serum.

\subsection{Tissue sample collection.}

The liver of both experimental and control groups fishes just after 24, 48, 72, and 96 hours exposures were dissected out and washed thoroughly with $0.9 \mathrm{~N}$ saline solutions then homogenized and centrifuged at $3500 \mathrm{rpm}$ for 20 minutes to obtained supernatant. The serum and supernatants were used for the analysis of total lipids [81], cholesterol [82], phospholipid [83], and triglycerides by the method after Foster and Dunn [84].

\subsection{Statistical analysis.}

The biostatistical analysis was performed using advanced numerical tools and the data presented in the manuscript as mean \pm standard error (S.E.) unless otherwise stated. Student's t-test calculated the statistical significance of the difference between the control and experimental group.

\section{Results and Discussion}

Lipid is an important energy source and an essential component of the cell membrane (phospholipids and cholesterol). Besides this, they also play a significant role as messengers in 
signal transduction pathways and molecular recognition processes [74]. Hence, any changes in lipid metabolism would signal to impairment of these crucial pathways. In the present study, total lipids, total cholesterol, and phospholipids levels in serum were significantly high in 96 hours effluent exposed fishes compared to control (Table 1). Similar observations have also been made in freshwater fishes inhabiting polluted water by some researchers [85, 86]. Cholesterol, phospholipids, and triglycerides combine to form total lipids; hence increase in serum phospholipids and cholesterol level is directly proportional to total lipids [87, 88]. Liver dysfunction and disturbance of lipid metabolism also favor elevation in phospholipids and cholesterol $[89,90]$. Being an important structural component of plasma membrane, lipids maintain fluidity, so membrane degeneration of hepatic cells could be another possible cause of their elevation [91, 92].

In the present study, an elevated level of serum cholesterol in Channa punctatus exposed to paper mill effluent might indicate liver dysfunction, which normally esterifies cholesterol and excrete a part of it with the bile (Table 1) [92, 93]. Katti and Sathyanesan demonstrated that blood cholesterol elevation might be due to the inhibition of enzymes involved in lipid metabolism by toxic effluents leading to the slow removal of lipids from blood [94]. High cholesterol levels in the serum could also be due to lipid transport from the synthesis site for subsequent utilization either through oxidation or a process of the gradual instauration of lipid molecules [86, 95, 96].

In the present study, serum triglycerides level was significantly declined in test fish compared to control after 96 hours exposure to sublethal concentration of paper mill effluent (Table 1) [97, 98]. Low triglycerides level in blood was also reported in copper sulfate exposed fish, Labeo rohita [99]. It has been reported that constant energy demand leads to the mobilization of triglycerides since these serve as lipid depots [74, 100]. A decline in triglycerides could also be correlated to their utilization in membrane biogenesis or might be due to improper synthesis of triglycerides in the hepatic cells [74, 101].

Table 1. Alterations in serum lipid profile level in paper mill effluent exposed fish, Channa punctatus $(\mathrm{N}=6)$.

\begin{tabular}{|c|c|c|c|c|}
\hline \multirow{2}{*}{$\begin{array}{l}\text { Experimental } \\
\text { Group }\end{array}$} & \multicolumn{4}{|c|}{ Treatment of fish to sublethal concentration $(10 \%)$ at different periods } \\
\hline & 24 hrs & 48 hrs & $72 \mathrm{hrs}$ & $96 \mathrm{hrs}$ \\
\hline \multicolumn{5}{|c|}{ Total Lipid(mg/dl) } \\
\hline Control & $474.21 \pm 0.42$ & $472.57 \pm 0.34$ & $473.51 \pm 0.29$ & $471.28 \pm 0.37$ \\
\hline Treated & $482.87 \pm 0.25$ & $496.24 \pm 0.26$ & $512.28 \pm 0.21$ & $532.18 \pm 0.31 *$ \\
\hline$\%$ increase over control & $+1.83 \%$ & $+5.01 \%$ & $+8.19 \%$ & $+12.92 \%$ \\
\hline \multicolumn{5}{|c|}{ Total Cholesterol (mg/dl) } \\
\hline Control & $142.32 \pm 0.41$ & $140.58 \pm 0.25$ & $141.26 \pm 0.29$ & $141.59 \pm 0.28$ \\
\hline Treated & $163.28 \pm 0.24$ & $179.26 \pm 0.27$ & $192.25 \pm 0.31 *$ & $218.32 \pm 0.06^{*}$ \\
\hline$\%$ increase over control & $+14.73 \%$ & $+27.51 \%$ & $+36.09 \%$ & $+54.19 \%$ \\
\hline \multicolumn{5}{|c|}{ Phospholipids (mg/dl) } \\
\hline Control & $187.11 \pm 0.31$ & $188.12 \pm 0.22$ & $187.52 \pm 0.32$ & $188.54 \pm 0.28$ \\
\hline Treated & $193.87 \pm 0.12$ & $205.12 \pm 0.16$ & $219.34 \pm 0.27$ & $241.58 \pm 0.19 *$ \\
\hline$\%$ increase over control & $+3.61 \%$ & $+9.04 \%$ & $+16.97 \%$ & $+28.13 \%$ \\
\hline \multicolumn{5}{|c|}{ Triglycerides $(\mathrm{mg} / \mathrm{dl})$} \\
\hline Control & $138.58 \pm 0.21$ & $138.15 \pm 0.16$ & $137.87 \pm 0.19$ & $138.21 \pm 0.22$ \\
\hline Treated & $122.25 \pm 0.16$ & $114.98 \pm 0.18$ & $99.28 \pm 0.17 *$ & $79.44 \pm 0.12 *$ \\
\hline$\%$ decrease over control & $-11.98 \%$ & $-16.77 \%$ & $-27.99 \%$ & $-42.52 \%$ \\
\hline
\end{tabular}

Lipid content is an essential organic constituent of the tissues of all animals. It plays a key role in energy metabolism as they are the best energy producers of the body next to carbohydrates $[102,103]$. It acts as a reversed depot of energy from where it is supplied and when required [94]. Chezhian et al. reported that lipids are vital to embryogenesis, providing two-third of energy by oxidation [104]. 
Table 2. Alterations in lipid profile of liver in paper mill effluent exposed fish, Channa punctatus (N=6).

\begin{tabular}{|c|c|c|c|c|}
\hline \multirow{2}{*}{$\begin{array}{c}\text { Experimental } \\
\text { Group }\end{array}$} & \multicolumn{4}{|c|}{ Treatment of fish to sublethal concentration $(10 \%)$ at different period } \\
\hline & $24 \mathrm{hrs}$ & $48 \mathrm{hrs}$ & $72 \mathrm{hrs}$ & $96 \mathrm{hrs}$ \\
\hline \multicolumn{5}{|c|}{ Total Lipids $(\mathrm{mg} / \mathrm{l})$} \\
\hline Control & $6.15 \pm 0.11$ & $6.18 \pm 0.12$ & $6.11 \pm 0.18$ & $6.13 \pm 0.17$ \\
\hline Treated & $6.05 \pm 0.24$ & $5.84 \pm 0.23$ & $5.69 \pm 0.28$ & $5.46 \pm 0.31 *$ \\
\hline$\%$ decrease over control & $-1.63 \%$ & $-5.50 \%$ & $-6.87 \%$ & $-10.93 \%$ \\
\hline \multicolumn{5}{|c|}{ Total Cholesterol $(\mathrm{mg} / \mathrm{l})$} \\
\hline Control & $4.09 \pm 0.18$ & $4.08 \pm 0.15$ & $4.07 \pm 0.17$ & $4.08 \pm 0.14$ \\
\hline Treated & $4.24 \pm 0.17$ & $4.29 \pm 0.14$ & $4.35 \pm 0.15$ & $4.49 \pm 0.21 *$ \\
\hline$\%$ increase over control & $+3.67 \%$ & $+5.15 \%$ & $+6.44 \%$ & $+10.05 \%$ \\
\hline \multicolumn{5}{|c|}{ Phospholipids (mg/l) } \\
\hline Control & $18.28 \pm 0.14$ & $18.54 \pm 0.19$ & $18.35 \pm 0.18$ & $18.44 \pm 0.15$ \\
\hline Treated & $17.62 \pm 0.11$ & $17.22 \pm 0.15$ & $16.69 \pm 0.17$ & $16.25 \pm 0.32 *$ \\
\hline$\%$ decrease over control & $-3.61 \%$ & $-7.12 \%$ & $-9.04 \%$ & $-11.88 \%$ \\
\hline \multicolumn{5}{|l|}{ Triglycerides $(\mathrm{mg} / \mathrm{l})$} \\
\hline Control & $3.14 \pm 0.07$ & $3.15 \pm 0.08$ & $3.16 \pm 0.12$ & $3.14 \pm 0.15$ \\
\hline Treated & $3.28 \pm 0.09$ & $3.45 \pm 0.34$ & $3.69 \pm 0.17 *$ & $3.98 \pm 0.19 *$ \\
\hline$\%$ increase over control & $+4.46 \%$ & $+8.70 \%$ & $+14.36 \%$ & $+26.75 \%$ \\
\hline
\end{tabular}

In the present study, a significant decline in total lipid content in the liver was recorded in freshwater test fish, Channa punctatus exposed to sublethal concentration of paper mill effluent (Table 2). Some workers also observed that industrial effluent decreases the total lipid content in different tissue of fishes [105-107]. A decrease in total lipid in tissues might be due to a sudden decrease in glycogen content in the same tissue, an intermediate energy source during toxic stress conditions [108, 109]. After glycogen, lipid content may be used for energy production to overcome toxic stress. Another region of depletion of lipid content may be due to lipolysis or the mitochondrial injury, which impaired the function of TCA cycle and the fatty acid oxidation mechanism [110-112]. The decreased level of tissue lipid content may be due to liver dysfunction or mobilization of glycerol or inhibition of oxidative phosphorylation [113, 114].

In the present study, a significant increase in triglycerides and cholesterol was noticed in the liver of test fish Channa punctatus, while there was a significant decrease in the phospholipid in the liver after 96 hours of exposure effluent (Table 2). A similar result was also observed in the reproductive tissue of Channa striatus exposed to tannery effluent by Sivachandran and Sultana [115]. In the present investigation, the increased level of liver triglyceride and cholesterol suggests that paper mill effluent interference in the process of steroidogenesis or vitellogenesis in the test fish [116]. The accumulation of triglycerides in the liver is due to impaired glycerol utilization, associated with disturbances in the biochemical process in hepatic cells [117]. The available glycerides are utilized to provide energy during effluent stress condition and their survival [118]. In the present study, decreased phospholipid level in the liver of effluent exposed fish was the sign of structural damage of hepatic cell membrane [119].

\section{Conclusions}

Like glycogen, Lipids are also a storage form of energy in aquatic fauna. The present study plays an important role in industry effluents risk assessment using a fish model that is a key indicator of environmental toxicity. The significant increase in serum lipid with decrease in liver of test fish, Channa punctatus Bloch (Actinoptrygii: Channidae) after exposure to sub lethal concentration of paper mill effluent. A decrease in the total lipid content of the liver with elevated serum lipid level in effluent exposed test fish suggests that lipid might have been 
utilized in energy production for other metabolic functions during toxic stress conditions. The changes in biochemical constituents of serum and tissue are important to indicate the susceptibility of organ systems to toxicants by changing their function. The results may help understand the toxicity of the industrial effluents in the natural aquaculture system and may work as pre- alarming indicators of chemotoxicity in the freshwater fish, Channa punctatus. It can be concluded that paper mill effluent was toxic to the aquatic animals, and thus it is imperative to understand its ecotoxicological implications. However, the effluent is being regularly added to the water bodies in the natural environment, and the fish remains continuously in contact with a higher concentration of the chemicals. Thus, there is a greater risk in nature than observed under the experimental conditions. Therefore, further studies are required to arrive at a definite conclusion and to find out the active principle of the hazardous potential of the paper mill effluent.

\section{Funding}

This research received no external funding.

\section{Acknowledgments}

SP is grateful to the Principal and Management Committee, M.L.K. (P.G) College, Balrampur (U.P.), for providing necessary laboratory facilities. SKU is thankful to the Professor and Head, Department of Biotechnology, Maharishi Markandeshwar (Deemed to be University), Mullana-Ambala (HR), India, for granting permission to collaborative research work.

\section{Conflicts of Interest}

The authors declare no conflict of interest.

\section{References}

1. Upadhyay, S.K. Transmission dynamics ad environmental influence on food borne parasitic helminthes of the Gangetic plains and central west coast of India. Unpubl. D.Phil Thesis, University of Allahabad, India 2012, 400.

2. Srivastava, V.; Ismail, S.A.; Singh, P.; Singh, R.P. Urban solid waste management in the developing world with emphasis on India: challenges and opportunities. Rev. Env. Sci. Biotechnol. 2015, 14, 317-337, https://doi.org/10.1007/s11157-014-9352-4.

3. Kaur, S. The effect of urbanization on environment in India. Int. J. Emerg. Technol. 2017, 8, 122-126.

4. Upadhyay, S.K.; Babita; Singh, R. The diversity and bioecology of cestodes in freshwater snakehead fish Channa sp. (Bloch) with a checklist of tapeworms previously reported from this fish in India. In: Parasitology Taxonomy and Bioecology. ed. Upadhyay, S.K. Write and Print Publications, New Delhi, 2019; pp. 17-37.

5. Singh, S.; Tiwari, R.K.; Pandey, R.S. Evaluation of acute toxicity of triazophos and deltamethrin and their inhibitory effect on AChE activity in Channa punctatus. Toxicol. Rep. 2018, 5, 85-89, https://doi.org/10.1016/j.toxrep.2017.12.006.

6. Ferronato, N.; Torretta, V. Waste mismanagement in developing countries: A review of Global issues. Int. J. Env. Res. Publ. Hlth. 2019, 16, https://doi.org/10.3390/ijerph16061060.

7. Upadhyay, S.K.; Singh, R.; Babita; Panwar, P.; Singh, D.P.; Rani, K.; Yadav, D. Population ecology of parasitic helminthes Oncodiscus Yamaguti, 1934 (Cestoda: Bothriocephalidae) in Greater lizardfish Saurida tumbil Bloch (Aulopiformes: Synodontidae) from the coast of Visakhapatnam, Bay of Bengal. Bull. Pure Appl. Sci. Zool.2020, 39A, 379-386, https://doi.org/10.5958/2320-3188.2020.00042.X.

8. Kaur, R.; Wani, S.P.; Singh, A.K.; Lal, K. Wastewater production, treatment and use in India. $2^{\text {nd }}$ Reg. Wrkshp, Proj. Safe Wastewater Agri. 2012, pp. 16-18.

9. Soumitra, N. Effect of paper mill effluents on morphological and hematological indices of Amblyceps mangois. J. Fish. Aquat. Sci.2016, 11, 225-231, https://doi.org/10.3923/jfas.2016.225.231. 
10. Upadhyay, S.K. Autogenicity and precocious development of Sturdynema multiembryonata in Xenentodon cancila (Osteichthyes: Belonidae) from the Gangetic ecosystem. Bull. Pure Appl. Sci. Zool. 2020, 39A, 3645.

11. Sepúlveda, M.S.; Gallagher, E.P.; Gross, T.S. Physiological Changes in Largemouth Bass Exposed to Paper Mill Effluents Under Laboratory and Field Conditions. Ecotoxicol. 2004, 13, 291-301, https://doi.org/10.1023/B:ECTX.0000033087.97096.f4.

12. Jaiswal, N.; Upadhyay, S.K.; Malhotra, A.; Malhotra, S.K. Ecological morphotaxometry of trematodes of garfish (Teleostomi: Belonidae) from Gangetic riverine ecosystem in India. III. Principal Component Analysis for hydrobiological correlates to dynamics of infections by Cephalogonimus yamunii (Upadhyay, Jaiswal, Malhotra and Malhotra, 2012). J. Parasit. Dis. 2014, 38, 153-162, https://doi.org/10.1007/s12639012-0200-6.

13. Kumar, S.; Smith, S. R.; Fowler, G.; Velis, C.; Kumar, S.J.; Arya, S.; Rena, K.R.; Cheeseman, C. Challenges and opportunities associated with waste management in India. Royal Soc. Open Sci. 2017, 4, https://doi.org/10.1098/rsos.160764.

14. Upadhyay, S.K. Effect of pesticides exposure on human health and reproductive life. J. Complement. Med. Alt. Hlthcr. 2019, 10.

15. Liney, K. E.; Hagger, J.A.; Tyler, C.R.; Depledge, M.H.; Galloway, T.S.; Jobling, S. Health effects in fish of long-term exposure to effluents from wastewater treatment works. Env. Hlth. Perspect. 2006, 114, 81-89, https://doi.org/10.1289/ehp.8058.

16. Carey, R.O.; Migliaccio, K.W. Contribution of wastewater treatment plant effluents to nutrient dynamics in aquatic systems: A review. Env. Mgt.2009, 44, 205-217, https://doi.org/10.1007/s00267-009-9309-5.

17. Singh, U.; Singh, S.; Tiwari, R.K.; Pandey, R.S. Water pollution due to discharge of industrial effluents with special reference to Uttar Pradesh, India- A review. Int. Arch. App. Sci. Technol. 2018, 9, 111-121.

18. Jaishankar, M.; Tseten, T.; Anbalagan, N.; Mathew, B.B.; Beeregowda, K.N. Toxicity, mechanism and health effects of some heavy metals. Interdiscipl. Toxicol. 2014, 7, 60-72, https://doi.org/10.2478/intox-2014-0009.

19. Upadhyay, S.K.; Yadav, D.; Pathak, R.K. The impact of water quality on the population distribution pattern of cephalogonimid trematodes Cephalogonimus yamunii in fresh water fish Heteropneustes fossilis at Allahabad, Uttar Pradesh. J. Kalash Sci. 2015, 3, 11-17.

20. Singh, A.K.; Chandra, R. Pollutants released from the pulp paper industry: Aquatic toxicity and their health hazards. Aquat. Toxicol. 2019, 211, 202-216, https://doi.org/10.1016/j.aquatox.2019.04.007.

21. Pandey, A.; Jaiswar, S.P.; Ansari, N.G.; Deo, S.; Sankhwar, P.; Pant, S.; Upadhyay, S.K. Pesticide risk and recurrent pregnancy loss in females of subhumid region of India. Nig. Med. J. 2020, 61, 55-59, https://doi.org/10.4103/nmj.NMJ_117_18.

22. Bharti, S.; Rasool, F. Analysis of the biochemical and histopathological impact of a mild dose of commercial malathion on Channa punctatus (Bloch) fish. Toxicol. Rep. 2021, 25, 443-455, https://doi.org/10.1016/j.toxrep.2021.02.018.

23. Kumar, A.; Singh, R.; Upadhyay, S.K.; Kumar, S.; Charaya, M.U. Biosorption: The removal of toxic dyes from industrial effluent using phytobiomass- A review. Plant Arch. 2021, 21, 1320-1325, https://doi.org/10.51470/PLANTARCHIVES.2021.v21.S1.207.

24. Singh, U.; Pandey, R.S. Fertilizer industry effluent induced hematological, histopathological and biochemical alterations in a stinging catfish, Heteropneustes fossilis (Bloch, 1794). Env. Sustain. Indicat. 2021, 10, https://doi.org/10.1016/j.indic.2021.100110.

25. Manna, G.K. Convener' s address: Impacts of environment on animals and aquaculture. Eds. Manna, G.K.; Jana, B.B. 1990; pp. 11-15.

26. Ahmad, I.; Hamid, T.; Fatima, M.; Chand, H.S.; Jain, S.K.; Athar, M.; Raisuddin, S. Induction of hepatic antioxidants in freshwater catfish (Channa punctatus Bloch) is a biomarker of paper mill effluent exposure. Biochem. Biophys. Acta. 2000, 1523, 37-48, https://doi.org/10.1016/s0304-4165(00)00098-2.

27. Upadhyay, S.K.; Jaiswal, N.; Malhotra, A.; Malhotra, S.K. Ecological morphotaxometry of trematodes of garfish (Teleostomi: Belonidae) from Gangetic riverine ecosystem in India. I. Morphology and taxometric assessment of by Cephalogonimus yamunii n.sp. J. Parasit. Dis. 2013, 37, 218-224, https://doi.org/10.1007/s12639-012-0169-1.

28. Bhattacharya, M.; Patnaik, S.C. Mutagenic effect of discharged effluents from a paper mill at choudwar tested through micronucleus assay in wild rat. $9^{\text {th }}$ All India Cong. Chandigarh Abst. 1996, 51-56.

29. Kushwaha, B.; Nagpure, N.S.; Srivastava, S.; Ravindra, K.; Verma, M.S. Variation of micronuclei in peripheral blood cells of Channa punctatus. Ind. J. Anim. Sci. 2003, 73, 1192-1193.

30. Singh, M.; Yadav, M.; Singh, R.; Kumar, V.; Sehrawat, N.; Upadhyay, S.K. Development of water quality criteria for Fenneropenaeus indicus against arsenic by flow-through system in the central west coast of India at Goa. Bull. Pure Appl. Sci. Zool.2019, 38A, 144-149, https://doi.org/10.5958/2320-3188.2019.00021.4.

31. Yadav, K.K.; Trivedi, S.P. Evaluation of genotoxic potential of chromium (VI) in Channa punctatus fish in terms of chromosomal aberrations. Asian Pac. J. Cancer Prev. 2006, 7, 472-467.

32. Malik, M.K.; Kumar, P.; Seth, R.; Rishi, S. Genotoxic effect of paper mill effluent on chromosomes of fish Channa punctatus. Curr. World Env.2009, 4, 353-357, http://dx.doi.org/10.12944/CWE.4.2.13. 
33. Singh, D.P.; Upadhyay, S.K.; Sharma, V.; Kumar, N. Effect of endosulfan on ATPase activity in liver, kidney and muscles of Channa punctatus and their recovery response. Bull. Pure Appl. Sci. Zool. 2018, 37A, 21-26, https://doi.org/10.5958/2320-3188.2018.00005.0.

34. Moyle, P.B.; Cech, J.J. Fishes:An Introduction to Ichthyology. $4^{\text {th }}$ edition. Prentice Hall, Upper Saddle Ridge, NJ, USA. 2000.

35. Kasumyan, A.O. Effects of chemical pollutants on foraging behavior and sensitivity of fish to food stimuli. J. Ichthyol.2001, 41, 76-87.

36. Kumar S.; Upadhyay, S.K. Pathogenesis of Flavobacterium colunare in fish of fresh water riverine ecosystem from eastern region of Uttar Pradesh, India. Int. J. Rec. Sci. Res. 2016, 7, 13676-13679.

37. Little, E.E.; Finger, S.E. Swimming behavior as an indicator of sublethal toxicity in fish. Env. Toxicol. Chem.1990, 9, 13-19, https://doi.org/10.1002/etc.5620090103.

38. Mossa, A.T.H.; Swelam, E.S.; Mohafrash, S.M.M. Sub-chronic exposure to fipronil induced oxidative stress, biochemical and histopathological changes in the liver and kidney of male albino rats. Toxicol. Rep.2015, 2, 775-784, https://doi.org/10.1016/j.toxrep.2015.02.009.

39. PCI. Top paper companies in India. Papermart, 2010.

40. Chandrasekhar, C. P. From dirigisme to neoliberalism: Aspects of the political economy of the transition in India In: Developmental politics in transition: The neoliberal era and beyond. eds. Chang, K.S.; Ben, F.; Linda, W. Int. Politi. Econ. Ser. London, UK. 2012; pp. 140-165, https://doi.org/10.1057/9781137028303_8.

41. Jaiswal, N.; Upadhyay, S.K.; Malhotra, A.; Malhotra, S.K. Multifactorial etiology of infections by larvae of Eustrongylides tubifex (Nematoda: Dioctophymidae) in silver whiting of the central west coast of India at Goa. Asian J. Biol. Sci.2013, 6, 21-39, https://doi.org/10.3923/ajbs.2013.21.39.

42. Upadhyay, S.K.; Jaiswal, N.; Malhotra, A.; Malhotra, S.K. Ecological morphotaxometry of trematodes of garfish (Teleostomi: Belonidae) from Gangetic riverine ecosystem in India. II. Correlation of seasonality and host biology with distribution pattern of Cephalogonimus yamunii n.sp. J. Parasit. Dis. 2013, 37, 211-217, https://doi.org/10.1007/s12639-012-0168-2.

43. Varma, M.S. India beats China in paper market growth despite dumping fears. The Financ. Exp.2019.

44. Upadhyay, S.K. Environmental impact on helminth parasites of fresh water garfish from river Yamuna at Allahabad, Uttar Pradesh, India. Proc. Zool. Soc. India 2017, 16, 63-75.

45. Simão, L.; Hotza D.; Raupp-Pereira F.; Labrincha J.A.; Montedo, O.R.K. Wastes from pulp and paper mills - a review of generation and recycling alternatives. Cerâm.São Paul. 2018, 64, https://doi.org/10.1590/036669132018643712414.

46. Mehmood, K.; Rehman, S.K.U.; Wang, J.; Farooq, F.; Mahmood, Q.; Jadoon, A.M.; Javed, M.F.; Ahmad, I. Treatment of pulp and paper industrial effluent using physicochemical process for recycling . Water 2019, 11,https://doi.org/10.3390/w11112393.

47. Babita; Panwar, P.; Upadhyay, S.K. A review on ecosegregation and parasitocoenosis of helminthes: Perspective to health and sustainability. Bull. Pure Appl. Sci. Zool. 2019, 38A, 40-51, https://doi.org/10.5958/2320-3188.2019.00005.6.

48. Teschke, K. Pulp and paper industry- industries based on biological resources. Encyclop. Occupat. Hlth. Saf. 2021.

49. C.P.P.R.I. Report on water conservation in pulp and paper industry by Central Pulp and Paper Research Institute Saharanpur, (UP), India. Cess Grant Auth. Develop. Counc Pulp Paper All. Indust. 2008.

50. Tewari, P.K.; Batra, V.S.; Balakrishnan, M. Efficient water use in industries: Cases from the Indian agrobased pulp and paper mills. J. Env. Mgt. 2009, 90, 265-273, https://doi.org/10.1016/J.JENVMAN.2007.09.001.

51. Prakash, S.; Singh, D. Impact of distillery effluent on behaviour and oxygen consumption of Cyprinus carpio (L.). Int. J. Sci. Res. Biol. Sci.2020, 7, 34-37.

52. Ram, C.; Rani, P.; Gebru, K.A.; Mariam-Abrha, M.G. Pulp and paper industry wastewater treatment: use of microbes and their enzymes. Phys. Sci. Rev.2020, 5, https://doi.org/10.1515/psr-2019-0050.

53. Naidu. B.R. Pulp and paper industry regulatory overview. Cent. Poll. Contl. Bd. India 2021, http://cca.urbanindustrial.in/live/hrdpmp/hrdpmaster/igep/content/e48745/e49028/e51797/e52844/02_PulpPaperSectorRegulatoryOverview_BRNaidu_CPCB.pdf. Accessed on: 18.05.2021.

54. Cabral, F.; Vasconcelos, E.; Goss, M.; Cordovil, C. The value, use, and environmental impacts of pulp-mill sludge addition to forest and agricultural lands in Europe. Env. Rev.1998, 6, 55-64, https://doi.org/10.1139/a98-004.

55. Sharan, K.K.; Mohammed, S.; Elango, S. Water pollution control in paper and pulp industry. Imp. J. Interdisc. Res. 2017, 3, 466-469.

56. Upadhyay, S.K.; Singh, R. Polyfactorial etiology on demography of parasitic allocreodoidean trematodes in the Gangetic ecosystem. AASCIT Amer. J. Biomed. Sci. Engg. 2018, 04, 17-23.

57. Nanware, S.S.; Bhure, D.B.; Upadhyay, S.K. Diversity of tapeworms from piscean, avian and mammalian hosts from Marathwada region (M.S.) India. Bull. Pure Appl. Sci. Zool. 2019, 38A, 120-125, https://doi.org/10.5958/2320-3188.2019.00013.5.

58. Bajpai, P. Microbial degradation of pollutants in pulp mill effluents. Adv. Appl. Microbiol. 2001, 48, 79-134, https://doi.org/10.1016/s0065-2164(01)48001-4. 
59. Haseena, M.; Malik, M.F.; Javed, A.; Arshad, S.; Asif, N.; Zulfiqar, S.; Hanif, J. Water pollution and human health.Env. Risk Assess. Remed. 2017, 1, https://doi.org/10.4066/2529-8046.100020.

60. Kumar, S.; Meena, H.M.; Verma, K. Water pollution in India: Its impact on the human health, causes and remedies. Int. J. Appl. Env. Sci. 2017, 12, 275-279.

61. Sharma, S.; Bhattacharya, A. Drinking water contamination and treatment techniques. Appl. Water. Sci. 2017, 7, 1043-1067, https://doi.org/10.1007/s13201-016-0455-7.

62. Upadhyay, S.K.; Babita; Panwar, P.; Kumar, S.; Nanware, S.S. Parasite-host interactions: A negative symbiotic association between organismse perspective to health and sustainability. In: Parasitology Taxonomy and Bioecology. ed. Upadhyay, S.K. Write and Print Publications, New Delhi, 2019; pp. 164-183.

63. Malhotra, A.; Jaiswal, N.; Upadhyay, S.K.; Kumar, S.; Malhotra, S.K. Parasite stress response in zoonoses of Cephalogonimus sp. Ind. J. Helminthol. (N.S.) 2009, 27, 73-80.

64. Firat, Ö.; Kargın, F. Biochemical alterations induced by $\mathrm{Zn}$ and $\mathrm{Cd}$ individually or in combination in the serum of Oreochromis niloticus. Fish Physiol. Biochem. 2010, 36, 647-653, https://doi.org/10.1007/s10695009-9337-3.

65. Shakir, H.A.; Qazi, J.I.; Chaudhry, A.S. Examining muscles of Cirrhinus mrigala for biochemical parameters as a bio-indicator of water pollution by municipal and industrial effluents into river Ravi, Pakistan. Int. Aquat. Res. 2014, 6, 221-228, https://doi.org/10.1007/s40071-014-0082-6.

66. Arya, A.; Sharma, G.D. Combined effects of cadmium and mecury on some biochemical and histochemical changes in liver, kidney and gills of Channa punctatus (Bloch). Int. J. Pharm. Pharm. Sci. 2015, 7, 117-120.

67. Pathan, T.S.; Sonawane, D.L.; Khillare, Y.K. Toxicity and behavioural changes in freshwater fish Rasbora daniconius exposed to paper mill effluent. Bot. Res. Int. 2009, 2, 263-266.

68. Moorthikumar, K.; Muthulingam, M. Impact of heavy metal nickel chloride on enzyme succinate dehydrogenase of freshwater fish Labeo rohita (Hamilton). Int. J. Curr. Res. 2011, 3, 115-119.

69. Upadhyay, S.K. Morphotaxonomy, histopathology and population dynamics of natural enoplid infections in wild rat, Rattus rattus of eastern Uttar Pradesh, India. AASCIT J. Biosci. 2018, 4, 22-27.

70. Tocher, D.R. Metabolism and functions of lipids and fatty acids in teleost fish. Rev. Fish. Sci. 2003, 11, 107184, https://doi.org/10.1080/713610925.

71. Upadhyay, S.K. Histopathological and distribution aspects of natural enoplid infections in hepatic tissue of wild rat, Rattus rattus in Allahabad. Ind. J. Helminthol. (N.S.) 2017, 36\&37, 51-55.

72. Casares, D.; Escribá, P.V.; Rosselló, C.A. Membrane lipid composition: Effect on membrane and organelle structure, function and compartmentalization and therapeutic avenues. Int. J. Mol. Sci. 2019, 20, https://doi.org/10.3390/ijms20092167.

73. Kay, J.G.; Fairn, G.D. Distribution, dynamics and functional roles of phosphatidylserine within the cell. Cell. Commun. Signal. 2019, 17,https://doi.org/10.1186/s12964-019-0438-z.

74. Van Meer, G.; Voelker D.R.; Feigenson G.W. Membrane lipids: where they are and how they behave? Nat. Rev. Mol. Cell Biol. 2008, 9, 112-124, https://doi.org/10.1038/nrm2330.

75. Gijare, S.S.; Raja, I.A.; Tantarpale, V.T.; Kulkarni, K.M. Lipid changes in the freshwater fish Ophiocephalus punctatus exposed to synthetic pyrethroid cypermethrin. Biosci. Biotech. Res. Comm. 2011, 4, $52-54$.

76. Kim, K. D.; Lim, S.G.; Kang, Y.J.; Kim, K.W.; Son, M.H. Effects of dietary protein and lipid levels on growth and body composition of juvenile far eastern catfish Silurus asotus. Asian-Austral J. Anim. Sci. 2012, 25, 369-374, https://doi.org/10.5713/ajas.2011.11089.

77. Qiu, H.; Jin, M.; Li, Y.; Lu, Y.; Hou, Y.; Zhou, Q. Dietary lipid sources influence fatty acid composition in tissue of large yellow croaker (Larmichthys crocea) by regulating triacylglycerol synthesis and catabolism at the transcriptional level. PloS one, 2017, 12, https://doi.org/10.1371/journal.pone.0169985.

78. Upadhyay, S.K.; Nanware, S.S. Parasitoses and histological consequences of Trichuris trichiura (Nematoda: Enoplida) in rodents, Rattus rattus (Mammalia: Rodentia). Asian J. Biol. Life Sci. 2020, 9, 74-78, https://doi.org/10.5530/ajbls.2020.9.11.

79. FAO. World review: The ten years since the world food conference urbanization, agriculture and food systems. State Food Agri. Org. UN, 1984, 10, 209.

80. Prakash, S.; Verma, A.K. Toxic effects of paper mill effluents on mortality, behaviour and morphology of snake headed fish, Channa punctatus (Bloch.). Int. J. Biol. Innovat. 2020, 2, 102-108, https://doi.org/10.46505/IJBI.2020.2204.

81. Barnes, H.; Blackstock, J. Estimation of lipids in marine animals and tissues: detailed investigation of the sulphophosphovanilun method for 'total' lipids. J. Exp. Mar. Biol. Ecol. 1973, 12, 103-118, https://doi.org/10.1016/0022-0981(73)90040-3.

82. Warnick, G.R. Measurement of cholesterol, triglycerides, and HDL using compact analysis systems. Clin. Lab. Med. 1989, 9, 73-88.

83. Marinetti, G.V. Chromatographic separation, identification and analysis of phospholipid. J. Lipid Res. 1962, $3,1-20$.

84. Foster, L.B; Dunn, R.T. Stable reagents for the determination of serum triglycerides by colorimetric hantzsob condensation method. J. Clin. Chem. 1973, 19, 338-340. 
85. Hanan, S.G.; El-Kasheif, M.A.; Ibrahim, S.A.; Authman, M.M.N. Effect of water pollution in El-Rahawy drainage canal on hematology and organs of freshwater fish Clarias gariepinus. World Appl. Sci. J. 2013, 21, 329-341.

86. Vaseem, H.; Banerjee, T.K. Contamination of the river Ganga and its toxic implication in the blood parameters of the major carp Labeo rohita (Ham). Env. Sci. Poll. Res. 2013, 20, 5673-5681, https://doi.org/10.1007/s11356-013-1570-8.

87. Cox, R.A.; García-Palmieri, M.R. Cholesterol, Triglycerides, and Associated Lipoproteins. In: Clinical Methods: The History, Physical, and Laboratory Examinations. 3rd edition eds., Walker, H.K.; Hall, W.D.; Hurst, J.W. Boston, Butterworths, Volume 32, 1990.

88. Feingold, K.R. Introduction to lipids and lipoproteins. Endotext, eds., Feingold, K.R.; Anawalt, B.; Boyce, A.; South Dartmouth MDText Inc. 2021.

89. Studeník, P. Poruchy lipidů u jaterních onemocnění [Lipid disorders in liver diseases]. Vnitr. Lek. Czech. 2000, 46, 547-548.

90. Arvind, A.; Osganian, S.A.; Cohen, D.E.; Corey, K.E. Lipid and lipoprotein metabolism in liver disease. Endotext, eds., Feingold, K.R.; Anawalt, B.; Boyce, A. South Dartmouth MDText Inc. 2019.

91. Banaee, M. Physiological dysfunction in fish after insecticides exposure. In: Development of safer and more effective technologies. ed. Trdan, S. IntechOpen 2013; https://doi.org/10.5772/54742.

92. Javed, M.; Ahmad, M.I.; Usmani, N.; Ahmad, M. Multiple biomarker responses (serum biochemistry, oxidative stress, genotoxicity and histopathology) in Channa punctatus exposed to heavy metal loaded waste water. Sci. Rep. 2017, 7, https://doi.org/10.1038/s41598-017-01749-6.

93. John, P.J. Alteration of certain blood parameters of freshwater teleost Mystus vittatus after chronic exposure to Metasystox and Sevin. Fish Physiol. Biochem. 2007, 33, 15-20, https://doi.org/10.1007/s10695-006-91127.

94. Katti, S.R.; Sathyanesan, A.G. Lead nitrate induced changes in lipid and cholesterol levels in the freshwater catfish Clarias batrachus. Toxicol. Lett. 1983, 19, 93-96, https://doi.org/10.1016/0378-4274(83)90267-9.

95. Pathan, T.S.; Thete, P.B.; Shinde, S.; Sonawane, D.; Khillare. Y. Histochemical changes in the liver of freshwater fish, Rasbora daniconius, exposed to paper mill effluent. Emir. J. Food Agri. 2017, 21, 71-78, https://doi.org/10.9755/ejfa.v21i2.5166.

96. Shelke, A. Comparative study of cholesterol alterations in a freshwater teleost fish, Amblypharyngodon mola exposure to heavy metals. The Bioscan. 2013, $8,1001-1003$.

97. Hasan, C.; Seyit, A. Changes in blood parameters of rainbow trout (Oncorhynchusmykiss Walbaum) after physical pollution. J. Appl. Anim. Res. 2006, 29, 77-80, https://doi.org/10.1080/09712119.2006.9706576.

98. Javed, M.; Usmani, N. An overview of the adverse effects of heavy metal contamination on fish health. Proc. Natl. Acad. Sci., India, Sect. Biol. Sci. 2019, 89, 389-403, https://doi.org/10.1007/s40011-017-0875-7.

99. Latif, A.; Khalid, M.; Ali, M. Evaluation of toxic stress of copper sulphate and lead nitrate on hematological and serum biochemical characteristics of freshwater cyprinid (Labeo rohita). Int. J. Curr. Engg. Technol. 2014, 4, 366-372.

100. Sheridan, M.A. Lipid dynamics in fish: aspects of absorption, transportation, deposition and mobilization. Comp. Biochem. Physiol. Pt. B. Comp. Biochem. 1988, 90, 679-690, https://doi.org/10.1016/03050491(88)90322-7.

101. Weil, C.; Lefèvre, F.; Bugeon, J. Characteristics and metabolism of different adipose tissues in fish. Rev. Fish Biol. Fisheries 2013, 23, 157-173, https://doi.org/10.1007/s11160-012-9288-0.

102.Gunstone, F.D.; Harwood, J.L.; Dijkstra, A.J. The lipid handbook . $3^{\text {rd }}$ edition. CRC Press, Boca Raton, 2007; pp. 1472.

103.Gurr, M.I.; Harwood, J.L.; Frayn, K.N.; Murphy, D.J.; Michell, R.H. Lipids: Biochemistry, biotechnology and health. $6^{\text {th }}$ edition. Wiley-Blackwell, 2016; pp. 391.

104.Chezhian, A.; Kabilan, N.; Kumar, S.T.; Senthamilselvan, D.; Sivakumari. K. Impact of common mixed effluent of sipcot industrial estate on histopathological and biochemical changes in estuarine fish Lates calcarifer. Curr. Res. J. Biol. Sci. 2010, 2, 201-209.

105. Maruthi, A.; Rao, R. Effect of sugar mill effluent on organic reserves of fish. Poll. Res. 2001, 20, $167-171$.

106. Amudha, P.; Sangetha G.; Mahalingam, S. Diary induced alterations in the protein, carbohydrate and lipid metabolism of fresh water teleost fish Oreochromis mossambicus. Poll. Res. 2002, 21, 51-53.

107.Revathi, K.; Gulati, S.; Sharief, D. Tannery effluent induced biochemical changes in larvivorous fish Gambusia affinis. Poll. Res. 2005, 24, 815-818.

108. Swapna, S.; Dhankkodi, B.; Manimengalai, M. Effect of textile bleaching effluent on the food utilization, oxygen consumption and biochemical composition of Cyprinus carpio. Poll. Res. 2006, 25, 741-745.

109. Kamaraj, C.; Thamilmani, K. Impact of biochemical parameters of freshwater fish Cirrhinus mrigala exposed to polycyclic aromatic hydrocarbon effluent. Int. J. Adv. Res. Biol. Sci. 2016, 3, 152-159, http://dx.doi.org/10.22192/ijarbs.2016.03.12.020.

110.Aon, M.A.; Bhatt, N.; Cortassa, S.C. Mitochondrial and cellular mechanisms for managing lipid excess. Front. Physiol. 2014, 5, https://doi.org/10.3389/fphys.2014.00282.

111. Wajner, M.; Amaral, A.U. Mitochondrial dysfunction in fatty acid oxidation disorders: insights from human and animal studies. Biosci. Rep.2015, 36, https://doi.org/10.1042/BSR20150240. 
112.Sander, M.; Violante, H.S.; Ventura, F.V.; Wanders, R.J.A. The biochemistry and physiology of mitochondrial fatty acid $\beta$-oxidation and its genetic disorders. Ann. Rev. Physiol. 2016, 78, 23-44, https://doi.org/10.1146/annurev-physiol-021115-105045.

113.Rui, L. Energy metabolism in the liver. Comp. Physiol. 2014, 4, 177-197, https://doi.org/10.1002/cphy.c130024.

114.Tao, Y.F.; Qiang, J.; Bao, J.W.; Chen, D.J.; Yin, G.J.; Xu, P.;Zhu, H.J. Changes in physiological parameters, lipid metabolism, and expression of microRNAs in genetically improved farmed tilapia (Oreochromis niloticus) with fatty liver induced by a high-fat diet. Front. Physiol. 2018, 9, https://doi.org/10.3389/fphys.2018.01521.

115. Sivachandran, R.; Sultana, M. Effect of tannery effluent on lipid profiles in reproductive tissues of freshwater fish Channa straitus. Int. J. Novel Trends Pharma. Sci. 2014, 4, 77-80.

116. Abalaka, S.E. Evaluation of the haematology and biochemistry of Clarias gariepinus as biomakers of environmental pollution in Tiga dam, Nigeria. Braz. Arch. Bio. Biotech. 2013, 56, 371-376, https://doi.org/10.1590/S1516-89132013000300004.

117.Javed, M.; Usmani, N. Stress response of biomolecules (carbohydrate, protein and lipid profiles) in fish Channa punctatus inhabiting river polluted by thermal power plant effluent. Saudi J. Bio. Sci. 2015, 22, 237242, https://doi.org/10.1016/j.sjbs.2014.09.021.

118. Reddy, J.K.; Rao, M.S. Lipid metabolism and liver inflammation: Pt. II. Fatty liver disease and fatty acid oxidation. Amer. J. Physiol. 2006, https://doi.org/10.1152/ajpgi.00521.2005.

119.Vasilyeva, O.B.; Sukhanova, L.V.; Glyzina, O.Y.; Sapozhnikova, Y.P.; Yakhnenko, V.M.; Ripatti, P.O.; Nazarova, M.A.; Nemova, N.N. Lipid composition in muscle and liver of sympatric coregonid fishes from Lake Baikal (Coregonus spp.) under common garden experiment. Contemp. Probl. Ecol. 2016, 9, 188-194, https://doi.org/10.1134/S1995425516020098. 